diabetes has been observed both in Europe and elsewhere. ${ }^{4}$ Our study period of 11 years was too short to provide an accurate analysis of any time trend in incidence. In fact, there seemed to be a non-linear, epidemic type variation, with a possible outbreak in 1985 and around the year 1991. It has recently been pointed out that IDDM is a rather atypical chronic disease in that its "epidemics" are evident and relatively common. ${ }^{5}$

In our study a typical seasonal variation in incidence was established.

Since the pathological process leading to IDDM may start years before the clinical onset, the epidemic variation, as well as the seasonal one, probably reflects the activity of triggering factors rather than aetiological factors.

Funded by the Ministry of Science and Technology in Serbia through the contract no 8774, 1991-95.

1 WHO study group. Diabetes mellitus. Geneva: WHO, 1985 9-20. Technical Report Series No 727.

2 Cochi SL, Edmonds LE, Dyer $\mathrm{K}$ et al. Congenital rubella syndrome in the United States, 1970-1985: on the verge of elimination. Am 7 Epidemiol 1989;129:349-61.

3 Green A, Gale EAM, Patterson CC for the EURODIAB ACE Study Group. Incidence of childhood-onset insulin ACE Study Group. Incidence of childhood-onset insulindependent diabetes mellit

4 Bingley PJ, Gale EAM. Rising incidence of IDDM in Europe. Diabetes Care 1989;12:289-95.

5 World Health Organisation DIAMOND Project Group on Epidemics. Childhood diabetes, epidemics, and epidemiology: An approach for controlling diabetes. $\mathrm{Am} \mathcal{f}$ Epidemiol 1992;135:803-16.

\title{
Alcohol consumption and obesity in the adult population of Spain
}

\author{
Juan L Gutiérrez-Fisac, Fernando Rodríguez-Artalejo, Carmen Rodríguez-Blas, \\ Juan del Rey-Calero
}

Although diverse research has shown that alcoholics tend to have lower body weights, the relationship between alcohol consumption and adiposity in the general population has not been well established: studies have yielded varied and inconsistent results, reporting positive, negative, or no clear associations. ${ }^{1}$ We examined the relationship between regular drinking, including the consumption of different kinds of alcohol, and obesity in the Mediterranean population of Spain.

Methods: We studied 10645 men and 11193 women aged 20-64 years interviewed in the Spanish national health survey carried out in $1987 .{ }^{2}$ Obesity was determined by calculating the Quetelet index (QI) (defined as weight $(\mathrm{kg}) / \mathrm{height}\left(\mathrm{m}^{2}\right)$ ) using self reported weight and height. Subjects were considered obese if their QI was $\geqslant 85$ th centile for age group and gender.

Alcohol consumption was measured by a quantity-frequency index adapted to the pattern of alcoholic beverage consumption in Spain. Information was gathered on the usual frequency of consumption and the quantity consumed for each type of beverage studied during the year before the interview. Subjects were classified by alcohol consumption in accordance with previous studies. ${ }^{3}$ The proportions in each drinking category were: $36.9 \%$ non-drinkers, $49.5 \%$ moderate drinkers, $6.9 \%$ heavy drinkers, and $4.9 \%$ excessive drinkers. To measure the association between alcohol consumption and obesity, we calculated the odds ratios (OR) for men and women using non-conditional logistic regression. ${ }^{4}$ Several variables were taken into account because of their potential confounding effect: age, education, size of community, smoking, leisure time physical activity, consumption of any med- ication for hypertension and heart conditions over the previous two weeks, and, current weight loss diet or any other special diet. We checked for the presence of a dose-response relationship by carrying out a weighted linear regression analysis of the ORs.

Results: The crude and adjusted ORs for obesity for different types of alcoholic drinks and at different levels of consumption in Spanish men and women are shown in the table. For total alcohol intake, the adjusted OR in men increases between occasional drinkers and excessive drinkers, from 0.92 to $1 \cdot 17$. This positive tendency was statistically significant $(p=0.011)$. In women, the observed effect was just the reverse, ORs $<1$ that decreased significantly as the amount of alcohol consumption rose were seen. This trend was also statistically significant $(\mathrm{p}<0.001)$.

With regard to wine, the ORs tend to be $>1$, especially in heavy and excessive drinkers, suggesting a positive association. The most important association for wine consumption and obesity was observed in women; their adjusted OR was substantial $(1 \cdot 75)$ in excessive drinkers and statistically significant in heavy drinkers $(1.46,95 \% \mathrm{CI}=1.05,2.03)$ who showed a dose-response relationship that was close to statistical significance $(p=0 \cdot 066)$.

Discussion: This paper describes the relationship between regular alcohol consumption and obesity in the Spanish population. Findings for men and women are opposed - that is, there is a weak positive association in men and a weak negative association in women. Other studies on the same subject have provided similar results. ${ }^{5}$ The negative relationship detected in women is one of 
Crude and adjusted odds ratios (OR) along with their respective 95\% confidence intervals (CI) for obesity among men and women at different levels of beer, wine, spirits, and total alcohol intake.

\begin{tabular}{|c|c|c|c|c|c|c|c|c|}
\hline & \multicolumn{4}{|l|}{ Men } & \multicolumn{4}{|c|}{ Women } \\
\hline & $O R$ & (CI 95\%) & Adj $O F$ & $(C I 95 \%)$ & $O R$ & (CI 95\%) & Adj $O$ & (CI 95\%) \\
\hline $\begin{array}{l}\text { Beer } \\
\text { Non-drinker } \\
\text { Moderate drinker } \\
\text { Heavy drinker } \\
\text { Excessive drinker } \\
\text { Two side p value for linear trend } \neq\end{array}$ & $\begin{array}{l}1 \dagger \\
0.96 \\
1.03 \\
1.02 \\
\quad 0\end{array}$ & $\begin{array}{l}0 \cdot 84,1 \cdot 10 \\
0 \cdot 88,1 \cdot 21 \\
0 \cdot 77,1 \cdot 35 \\
279\end{array}$ & $\begin{array}{l}1 \dagger \\
0.97 \\
0.94 \\
0.86 \\
\quad 0 .\end{array}$ & $\begin{array}{l}0 \cdot 80,1 \cdot 18 \\
0 \cdot 75,1 \cdot 18 \\
0 \cdot 61,1 \cdot 23 \\
1\end{array}$ & $\begin{array}{l}1 \dagger \\
0 \cdot 84 \\
0.57 \\
0.92 \\
\quad 0\end{array}$ & $\begin{array}{l}0 \cdot 84,1 \cdot 10 \\
0 \cdot 88,1 \cdot 21 \\
0 \cdot 77,1 \cdot 35 \\
33\end{array}$ & $\begin{array}{l}1 \dagger \\
0.99 \\
0.80 \\
1.73 \\
\\
0\end{array}$ & $\begin{array}{l}0 \cdot 83,1 \cdot 19 \\
0 \cdot 54,1 \cdot 18 \\
0 \cdot 75,4 \cdot 00 \\
9\end{array}$ \\
\hline $\begin{array}{l}\text { Wine } \\
\text { Non-drinker } \\
\text { Moderate drinker } \\
\text { Heavy drinker } \\
\text { Excessive drinker } \\
\text { Two side p value for linear trend }\end{array}$ & $\begin{array}{l}1 \dagger \\
0.92 \\
1 \cdot 10 \\
1 \cdot 22 \\
0\end{array}$ & $\begin{array}{l}0 \cdot 80,1 \cdot 05 \\
0 \cdot 94,1 \cdot 30 \\
1 \cdot 00,1 \cdot 50 \\
069\end{array}$ & $\begin{array}{l}1 \dagger \\
0.96 \\
1.07 \\
1.06 \\
\quad 0 .\end{array}$ & $\begin{array}{l}0 \cdot 81,1 \cdot 13 \\
0 \cdot 87,1 \cdot 32 \\
0 \cdot 78,1 \cdot 43 \\
8\end{array}$ & $\begin{array}{l}1 \dagger \\
0.80 \\
1.02 \\
1.02 \\
0\end{array}$ & $\begin{array}{l}0 \cdot 71,0 \cdot 90 \\
0 \cdot 78,1 \cdot 34 \\
0 \cdot 62,1 \cdot 67 \\
22\end{array}$ & $\begin{array}{l}1+ \\
1.01 \\
1.46 \\
1.75 \\
\\
\quad 0\end{array}$ & $\begin{array}{l}0 \cdot 84,1 \cdot 21 \\
1 \cdot 05,2 \cdot 03 \\
0 \cdot 96,3 \cdot 20 \\
6\end{array}$ \\
\hline $\begin{array}{l}\text { Spirits } \\
\text { Non-drinker } \\
\text { Moderate drinker } \\
\text { Heavy drinker } \\
\text { Excessive drinker } \\
\text { Two side p value for linear trend‡ }\end{array}$ & $\begin{array}{l}1 \dagger \\
0.95 \\
1 \cdot 14 \\
1 \cdot 29 \\
0\end{array}$ & $\begin{array}{l}0 \cdot 84,1 \cdot 08 \\
0.95,1 \cdot 37 \\
0.93,1 \cdot 79 \\
043\end{array}$ & $\begin{array}{l}1 \dagger \\
1 \cdot 01 \\
1 \cdot 10 \\
1 \cdot 18 \\
\quad 0 .\end{array}$ & $\begin{array}{l}0 \cdot 87,1 \cdot 17 \\
0 \cdot 87,1 \cdot 39 \\
0 \cdot 79,1 \cdot 77 \\
22\end{array}$ & $\begin{array}{l}1 \dagger \\
0 \cdot 70 \\
0 \cdot 54 \\
1 \cdot 13 \\
0\end{array}$ & $\begin{array}{l}0 \cdot 60,0 \cdot 82 \\
0 \cdot 25,1 \cdot 18 \\
0 \cdot 47,2 \cdot 71 \\
24\end{array}$ & $\begin{array}{l}1+ \\
0.89 \\
0.78 \\
1 \cdot 15 \\
\quad 0\end{array}$ & $\begin{array}{l}0 \cdot 74,1 \cdot 07 \\
0 \cdot 32,1 \cdot 87 \\
0 \cdot 36,3 \cdot 74 \\
9\end{array}$ \\
\hline $\begin{array}{l}\text { Total alcohol } \\
\text { Non-drinker } \\
\text { Occasional drinker } \\
\text { Moderate drinker } \\
\text { Heavy drinker } \\
\text { Excessive drinker } \\
\text { Two side p value for linear trend } \neq\end{array}$ & $\begin{array}{l}1 \dagger \\
0 \cdot 91 \\
0.96 \\
1 \cdot 08 \\
1 \cdot 24 \\
0\end{array}$ & $\begin{array}{l}0 \cdot 67,1 \cdot 23 \\
0 \cdot 81,1 \cdot 13 \\
0 \cdot 87,1 \cdot 33 \\
1 \cdot 00,1 \cdot 55 \\
020\end{array}$ & $\begin{array}{l}1 \dagger \\
0 \cdot 92 \\
1 \cdot 03 \\
1 \cdot 11 \\
1 \cdot 17 \\
\quad 0 .\end{array}$ & $\begin{array}{l}0 \cdot 66,1 \cdot 28 \\
0 \cdot 86,1 \cdot 23 \\
0 \cdot 88,1 \cdot 40 \\
0 \cdot 91,1 \cdot 51 \\
11\end{array}$ & $\begin{array}{l}1 \dagger \\
0 \cdot 89 \\
0 \cdot 74 \\
0 \cdot 64 \\
0 \cdot 61 \\
\quad 0\end{array}$ & $\begin{array}{l}0 \cdot 76,1 \cdot 05 \\
0 \cdot 66,0 \cdot 84 \\
0 \cdot 38,1 \cdot 07 \\
0 \cdot 28,1 \cdot 33 \\
27\end{array}$ & $\begin{array}{l}1 \dagger \\
0 \cdot 96 \\
0 \cdot 89 \\
0 \cdot 81 \\
0 \cdot 74\end{array}$ & $\begin{array}{l}0 \cdot 81,1 \cdot 15 \\
0 \cdot 78,1 \cdot 02 \\
0 \cdot 47,1 \cdot 42 \\
0 \cdot 33,1 \cdot 66 \\
01\end{array}$ \\
\hline
\end{tabular}

* Odds ratio adjusted by non-conditional logistic regression controlling for age, education, size of community, smoking, leisure time physical activity, consumption of medication for hypertension, heart conditions, weight loss and other diets.

† Reference category.

$¥$ Two side p-value for linear trend of the odds ratios for obesity and the level of alcohol and alcoholic beverages consumption.

the most consistent findings in the numerous studies in the field. ${ }^{1}$

When interpreting these data, various aspects of the methodology should be taken into account. Self reported measurements of height and weight may have biased the results. However, the resulting misclassification is moderate, according to estimates of sensitivity and specificity of obesity determined via self reported height and weight. ${ }^{6}$ Moreover, the cross sectional study design may have influenced the results, given a possible self selection bias on the part of drinkers. Although it was not possible to control for all relevant predictors of obesity, the results present a sufficiently valid description of the association between alcohol consumption and obesity in this population.

1 Hellerstedt WL. Jeffery RW, Murray DM. The association between alcohol intake and adiposity in the general population. Am $\mathcal{F}$ Epidemiol 1990;132:594-611.

2 Ministerio de Sanidad y Consumo. Encuesta National de Salud. Madrid: Ministerio de Sanidad y Consumo, 1989 9-17.

3 Regidor Poyatos E, Gutiérrez Fisac JL, De Mateo Ontañòn $\mathrm{S}$. Asociación entre el consumo habitual de alcohol y accidentes. Gac Sanit 1992;6:245-252.

4 Hosmer DW, Lemeshow S. Applied logistic regression. New York: John Wiley and Sons, 1989.

5 Williamson DF, Forman MF, Binkin NJ, Gentry EM, Remington PL, Trowbridge FL. Alcohol and body weight in

6 Nieto-Garcis of obesity: sensitivity and specificity using self-reported weight and height. Epidemiology 1990;1:146-52. 